\title{
Overlapping and co-occurrence pattern of Anastrepha species (Diptera, Tephritidae) in anthropic areas
}

\author{
Tayron Sousa Amaral 1* \\ Gleidyane Novais Lopes ${ }^{1}$ \\ Keiko Uramoto ${ }^{1}$ \\ Julio Marcos Melges Walder ${ }^{2}$ \\ Rodrigo de Souza Bulhões ${ }^{3}$ \\ Roberto Antonio Zucchi ${ }^{1}$ \\ ${ }^{1}$ Departamento de Entomologia e Acarologia, Escola Superior de Agricultura Luiz de Queiroz \\ Universidade de São Paulo, CEP 13418-900, Piracicaba - SP, Brasil \\ ${ }^{2}$ Laboratório de Irradiação de Alimentos e Radioentomologia \\ Centro de Energia Nuclear na Agricultura, Universidade de São Paulo, Piracicaba - SP, Brasil \\ ${ }^{3}$ Departamento de Estatística, Instituto de Matemática e Estatística, Universidade Federal da Bahia, Salvador - BA, Brasil \\ * Autor para correspondência \\ tayron.amaral@gmail.com
}

Submetido em 15/05/2017

Aceito para publicação em 30/10/2017

\section{Resumo}

Padrão de sobreposição e coocorrência de espécies de Anastrepha (Diptera, Tephritidae) em áreas antropizadas. $\mathrm{O}$ estudo foi realizado em duas áreas antropizadas (Fazenda Areão e Monte Olimpo) do campus "Luiz de Queiroz", em Piracicaba, SP. Foram analisados os dados de 52 coletas em 14 armadilhas tipo McPhail distribuídas nas duas áreas. Foram coletadas 1.583 fêmeas pertencentes a 14 espécies: Anastrepha amita Zucchi, A. barbiellinii Lima, A. bistrigata Bezzi, A. daciformis Bezzi, A. distincta Greene, A. fraterculus (Wiedemann), A. grandis (Macquart), A. manihoti Lima, A. montei Lima, A. obliqua (Macquart), A. pickeli Lima, A. pseudoparallela (Loew), A. serpentina (Wiedemann) e $A$. sororcula Zucchi. Na Fazenda Areão, foram coletados mais espécimes (1.041) do que no Monte Olimpo (542). A média de sobreposição de nicho foi maior que o esperado ao acaso para as duas áreas, portanto, os nichos ecológicos das espécies, em grande parte, se sobrepõem. Pelo padrão de coocorrência, a segregação não foi aleatória entre dois pares de espécies: A. pseudoparallela x A. obliqua (Fazenda Areão) e A. fraterculus x A. pseudoparallela (Monte Olimpo). A segregação indicou que pode haver competição por algum recurso em cada nicho. A análise também apresentou três pares agregados: $A$. bistrigata x A. montei e A. fraterculus x A. barbiellinii (Fazenda Areão) e A. fraterculus x A. bistrigata (Monte Olimpo), indicando que cada par ocorre concomitantemente, sem que haja interferência na permanência das populações dessas espécies nas áreas.

Palavras-chave: Flutuação populacional; Índices faunísticos; Moscas-das-frutas; Nichos ecológicos 


\section{Abstract}

This study was carried out in two anthropic areas (Fazenda Areão and Monte Olimpo) on the "Luiz de Queiroz" campus, University of São Paulo, Piracicaba, SP. We analyzed data from 52 collections of 14 McPhail traps distributed in both areas. A total of 1,583 females belonging to 14 species were collected, including Anastrepha amita Zucchi, A. barbiellinii Lima, A. bistrigata Bezzi, A. daciformis Bezzi, A. distincta Greene, A. fraterculus (Wiedemann), A. grandis (Macquart), A. manihoti Lima, A. montei Lima, A. obliqua (Macquart), A. pickeli Lima, A. pseudoparallela (Loew), A. serpentina (Wiedemann) and A. sororcula Zucchi. A greater number of specimens $(1,041)$ were collected at the Fazenda Areão compared to Monte Olimpo (542). The mean niche overlap was greater than expected at random for both areas; therefore, the ecological niches of the species largely overlap. The pattern of co-occurrence indicates that segregation was not random between two pairs of species: A. pseudoparallela $\times$ A. obliqua (Fazenda Areão) and A. fraterculus $\times$ A. pseudoparallela (Monte Olimpo). This segregation suggests that there may be competition for resources in each niche. The analysis also revealed three aggregated species pairs: A. bistrigata $\times$ A. montei, A. fraterculus $\times$ A. barbiellinii (Fazenda Areão), and $A$. fraterculus $\times$ A. bistrigata (Monte Olimpo), indicating that each pair occurs concomitantly without interfering with the permanence of the populations in these areas.

Key words: Ecological niches; Faunal indices; Fruit flies; Population fluctuation

\section{Introduction}

Species of the genus Anastrepha Schiner, 1868 occur in the American tropics and subtropics. Approximately 280 species are known, of which 120 species are recorded in Brazil (ZUCCHI, 2008). Females lay eggs almost exclusively in healthy fruits, on which the larvae breed. Several species are considered pests because their larvae feed on fruits of commercial value, and some species are of quarantine importance too.

Studies of the interactions of Anastrepha species in their niches have generally been neglected and have only recently been carried out in Brazil (LOPES et al., 2015; DEUS et al., 2016). In general, studies on the population dynamics of fruit flies are related to faunal analyses and without regard to interspecific competition. Thus, the dynamics of fruit fly populations have been studied based on biotic factors (e.g., population density, host availability) and abiotic factors (e.g., temperature, relative humidity). However, competition between populations is a factor that alters the structure and permanence of populations in a given area (DUYCK et al., 2004).

Interspecific competition may lead to reduced survival, preventing population growth through interference from other species and/or resource competition. The most aggressive species can prevent other species from having access to resources in an area
(BEGON et al., 1996). This interaction may result in the displacement of populations to other niches and may also cause population reduction, which can either facilitate coexistence between two populations or lead to species extinctions (GOTELLI; GRAVES, 1996).

When introduced into a new habitat, polyphagous species are more aggressive and can adapt better to the invaded environment, displacing native species (FITT, 1989). Population growth and immature development rates affect the permanence of introduced species. Some species of fruit flies release pheromones after posture, which helps to regulate interspecific competition among larvae (ROITBERG; PROKOPY, 1987). These aspects may vary between populations of the same species (DIAMANTIDIS et al., 2011).

The peaceful coexistence between two species can be conceptualized from the term "coexistence", which entails two species occupying the same location and using the same resources without competitive exclusion a long period of time (DUYCK et al., 2004). Thus, the overlap in resource utilization between species that co-occur peacefully should be relatively low to zero. However, when competing for limited resources, the niche overlap of two species should be high (GOTELLI; ELLISON, 2013).

This study evaluated the patterns of niche overlap and co-occurrence, as well as the interactions among 
Anastrepha species based on surveys of abundance and presence-absence data.

\section{Materials and methods}

\section{Experimental area}

The collections were carried out on the "Luiz de Queiroz" campus in Piracicaba, SP (22॰42’30" S, 47³8'00" W) from July 1998 to June 1999 (URAMOTO et al., 2003). Among the specimens collected throughout the campus, two areas, called the Fazenda Areão (west) and Monte Olimpo (east), separated by approximately $4 \mathrm{~km}$, were selected for this study (Figure 1).

The area of the "Luiz de Queiroz" campus is 874.3 ha, and the landscape at this site is formed by urban areas and agroecosystems composed of annual, perennial, and semi-perennial species, reforested areas, pastures, paved areas, buildings, and forest remnants (ALEXANDRINO et al., 2013).

\section{Collection and identification of fruit flies}

This study was based on Anastrepha species collected previously on the "Luiz de Queiroz" campus (URAMOTO et al., 2003; 2004). Thus, data were selected from seven traps hung in two extreme areas of the campus (Fazenda Areão and Monte Olimpo). McPhail-type traps with hydrolyzed corn protein were established weekly and hung on fruit fly host and non-host plants in each campus area (Table 1). Anastrepha fraterculus is being considered here in a broad sense, as this nomination refers to a complex of cryptic species.

FIGURE 1: Spatial distribution of the sampling points (yellow circles) in the study area.

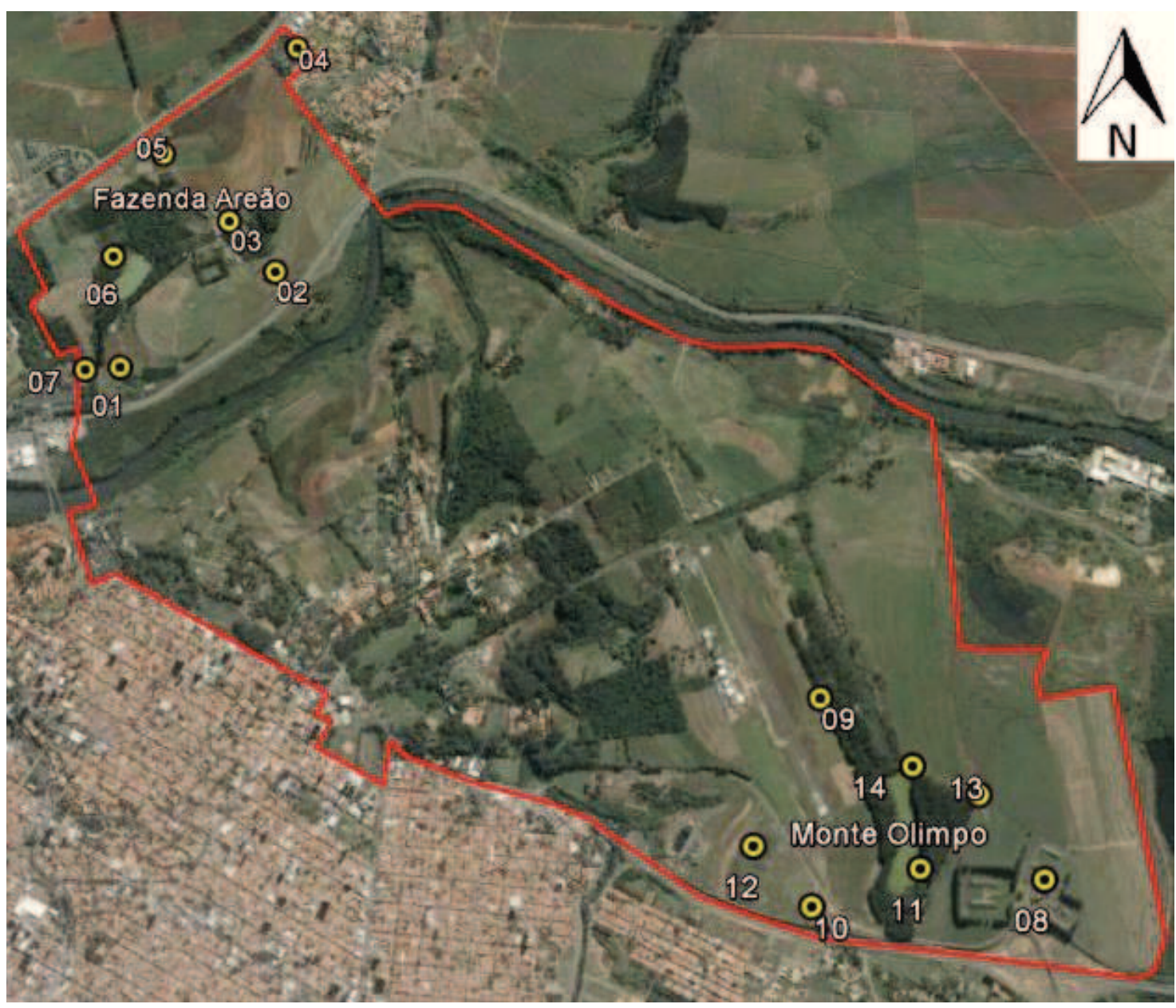


TABLE 1: Location and characterization of McPhail traps in the "Luiz de Queiroz" campus, Piracicaba, SP.

\begin{tabular}{|c|c|c|c|}
\hline Traps & $\begin{array}{l}\text { Coordinate } \\
\text { geographic }\end{array}$ & Altitude & Trees/Vegetation \\
\hline \multicolumn{4}{|c|}{ Fazenda Areão } \\
\hline 1 & $\begin{array}{l}22^{\circ} 42^{\prime} 02.1{ }^{\prime \prime} \mathrm{S} \\
47^{\circ} 38^{\prime} 41.9^{\prime \prime} \mathrm{W}\end{array}$ & $549 \mathrm{~m}$ & Mango* \\
\hline 2 & $\begin{array}{l}22^{\circ} 41^{\prime} 47.66^{\prime \prime} \mathrm{S} \\
47^{\circ} 38^{\prime} 19.9^{\prime \prime} \mathrm{W}\end{array}$ & $543 \mathrm{~m}$ & Citrus* \\
\hline 3 & $\begin{array}{l}22^{\circ} 41^{\prime} 40.7^{\prime \prime} \mathrm{S} \\
47^{\circ} 38^{\prime} 27.3 ” \mathrm{~W}\end{array}$ & $544 \mathrm{~m}$ & Passion fruit, coffee, horse chestnut*, mango and loquat \\
\hline 4 & $\begin{array}{l}22^{\circ} 41^{\prime} 14.1{ }^{\prime \prime} \mathrm{S} \\
47^{\circ} 38^{\prime} 19.3{ }^{\prime \prime} \mathrm{W}\end{array}$ & $574 \mathrm{~m}$ & Avocado, mango, citrus, guava and native plants* \\
\hline 5 & $\begin{array}{l}22^{\circ} 41^{\prime} 31.1 ” \mathrm{~S} \\
47^{\circ} 38^{\prime} 38.2^{\prime \prime} \mathrm{W}\end{array}$ & $694 \mathrm{~m}$ & Riparian forest* \\
\hline 6 & $\begin{array}{l}22^{\circ} 41^{\prime} 46.3^{\prime \prime} \mathrm{S} \\
47^{\circ} 38^{\prime} 44.4^{\prime \prime} \mathrm{W}\end{array}$ & $539 \mathrm{~m}$ & Riparian forest*, eucalyptus and pine \\
\hline 7 & $\begin{array}{l}22^{\circ} 42^{\prime} 02.6^{\prime \prime} \mathrm{S} \\
47^{\circ} 38^{\prime} 47.1{ }^{\prime \prime} \mathrm{W}\end{array}$ & $743 \mathrm{~m}$ & Mango* and native plants \\
\hline \multicolumn{4}{|c|}{ Monte Olimpo } \\
\hline 8 & $\begin{array}{l}22^{\circ} 43^{\prime} 07.0^{\prime \prime} \mathrm{S} \\
47^{\circ} 36^{\prime} 25.3^{\prime \prime} \mathrm{W}\end{array}$ & $656 \mathrm{~m}$ & $\begin{array}{l}\text { Cashew, persimmon, pitanga, jabuticaba, jatobá, guava, } \\
\text { citrus, avocado*, acerola, 'Sicilian' Lemon and banana }\end{array}$ \\
\hline 9 & $\begin{array}{l}22^{\circ} 42^{\prime} 40.5^{\prime \prime} \mathrm{S} \\
47^{\circ} 37^{\prime} 57.5^{\prime \prime} \mathrm{W}\end{array}$ & $611 \mathrm{~m}$ & Riparian forest* and eucalyptus \\
\hline 10 & $\begin{array}{l}22^{\circ} 43^{\prime} 11.5^{\prime \prime} \mathrm{S} \\
47^{\circ} 36^{\prime} 57.5^{\prime \prime} \mathrm{W}\end{array}$ & $501 \mathrm{~m}$ & $\begin{array}{l}\text { Mango, 'Tahiti' Lemon, avocado*, 'Sicilian' Lemon and } \\
\text { 'Ponkan'orange }\end{array}$ \\
\hline 11 & $\begin{array}{l}22^{\circ} 43^{\prime} 06.2^{\prime \prime} \mathrm{S} \\
47^{\circ} 36^{\prime} 42.5^{\prime \prime} \mathrm{W}\end{array}$ & $525 \mathrm{~m}$ & Guava, pitanga, blackberry and riparian forest* \\
\hline 12 & $\begin{array}{l}22^{\circ} 43^{\prime} 04.1^{\prime \prime} \mathrm{S} \\
47^{\circ} 37^{\prime} 05.8^{\prime \prime} \mathrm{W}\end{array}$ & $572 \mathrm{~m}$ & Citrus* \\
\hline 13 & $\begin{array}{l}22^{\circ} 42^{\prime} 56.5^{\prime \prime} \mathrm{S} \\
47^{\circ} 36^{\prime} 34.4^{\prime \prime} \mathrm{W}\end{array}$ & $699 \mathrm{~m}$ & Eucalyptus*, sorghum, sugar cane \\
\hline 14 & $\begin{array}{l}22^{\circ} 42^{\prime} 53.1^{\prime \prime} \mathrm{S} \\
47^{\circ} 36^{\prime} 43.7^{\prime \prime} \mathrm{W}\end{array}$ & $586 \mathrm{~m}$ & Riparian forest, pine, eucalyptus, bamboo, native plant* \\
\hline
\end{tabular}

* Trap.

\section{Meteorological data}

The mean values of the region were used for the respective collection days and were obtained from the database of the automatic meteorological station of the Engineering and Biosystems Department of the "Luiz de Queiroz" campus, available at $<\mathrm{http}$ ://www.esalq. usp.br/departamentos/leb/postoaut.html>.

\section{Niche overlap analysis}

The data from each area were organized into temporal matrices of abundance where each row represented one species, each column represented one sample, and each entry corresponded to the proportional abundance of one species. The average niche overlap among species pairs was calculated based on the niche overlapping indices by Pianka and Czechanowski (FEINSINGER et al., 1981). These index values range from zero (0) to one (1.0) for a pair of species that do not co-occur and those that present maximum temporal overlap, respectively. The TimeOverlap program (version 1.0) was used to estimate these indices using a randomization algorithm in Rosario Version 1.0 (CASTRO-ARELLANO et al., 2010), which treats each 
year as a circular time interval. The overlapping data were also analyzed by the RA3 algorithm in the EcoSim program version 7.72 (GOTELLI; ENTSMINGER, 2012), which changes the distribution of proportional abundances for each species between the different time periods (LOPES et al., 2015).

\section{Co-occurrence analysis}

Species co-occurrence patterns were analyzed with the original abundance data of each species in a sample and the incidence data (presence or absence of each species in the sample) (ULRICH, 2006; ULRICH; GOTELLI, 2010). The statistical significance of each pair of species was calculated using the PAIRS statistical program (ULRICH, 2008) by applying the fixed-fixed null model, which randomizes the occurrence of presences and absences while preserving the sums of rows and columns of the original matrix (GOTELLI, 2000; LOPES et al., 2015).

The pairs of species obtained were analyzed according to the average temperature and day of collection (Appendix 1), verifying the significance of the relationships. We carried out these analyses and generated all graphics in the software $\mathrm{R}$ version 3.0.1 (R CORE TEAM, 2013).

\section{Population fluctuations}

Analyses of population fluctuations were performed only for the pairs obtained. Data were collected from each species and the SAS program (version 9.3) was used for analyses of geometric means to make the data sharper, thereby eliminating the deforming effects (EKK et al., 1980).

\section{Results}

\section{Anastrepha species}

Among the 52 collections held at Fazenda Areão and Monte Olimpo, 1,583 females belonging to 14 Anastrepha species were captured (Table 2). In general, the most abundant species in the two areas, $A$. fraterculus, A. pseudoparallela and A. obliqua, were also the most abundant in a survey with 84 traps throughout the campus (URAMOTO et al., 2003).

More specimens were collected $(1,041)$ at the Fazenda Areão site, representing eleven species and about $66 \%$ of the total specimens collected in the two areas. Anastrepha fraterculus was the most abundant species with $691(66 \%)$ specimens, followed by $A$. pseudoparallela $(198 ; 19 \%)$ and A. obliqua $(81 ; 7 \%)$. The species with the lowest occurrence were $A$. distincta and $A$. amita (one and two individuals, respectively). In trap 3 (area with passion fruit, coffee, horse chestnut, mango and loquat), the highest number of individuals (355) were collected, representing eight species. However, $88 \%$ of the specimens collected in this trap belonged to $A$. fraterculus. In traps 6 and 7 (both riparian forest), $98 \%$ of the $A$. pseudoparallela specimens were collected (Table 2).

In trap 1 (area with mango), only 60 specimens were captured, representing $5 \%$ of the total collected in Fazenda Areão. Anastrepha daciformis was collected exclusively at Fazenda Areão (Table 2).

At Monte Olimpo, 542 specimens (34\% of the total) were collected and included 13 species. In this area, the largest number of individuals (426; 78\%) also belonged to $A$. fraterculus, followed by $A$. pseudoparallela (46; 8\%) and A. obliqua (28; 5\%). Anastrepha distincta, A. manihoti, A. montei, A. pickeli and A. serpentina were each represented by a single specimen. Trap 8 (area with cashew, persimmon, Brazilian pitanga, jabuticaba, jatobá, guava, citrus, avocado, acerola, 'Sicilian' lemon and banana), which yielded the highest number of individuals $(225 ; 41 \%)$, was almost exclusively represented by $A$. fraterculus ( $89 \%$ of the specimens). This is the most anthropic portion of the Monte Olimpo area and is located in the vicinity of a fowl run. Traps 12 and 13 yielded the lowest number of specimens ( 8 individuals in each). Anastrepha grandis, A. serpentina and $A$. sororcula were collected only at Monte Olimpo (Table 2). 
TABLE 2: Anastrepha species captured in McPhail traps at Fazenda Areão and Monte Olimpo, Luiz de Queiroz campus, USP, Piracicaba, SP, from July 1998 to June 1999.

\begin{tabular}{|c|c|c|c|c|c|c|c|c|c|c|c|c|c|c|c|c|c|c|}
\hline \multirow{2}{*}{ Species } & \multicolumn{7}{|c|}{ Traps - Fazenda Areão } & \multirow{2}{*}{ Total } & \multirow{2}{*}{$(\%)$} & \multicolumn{7}{|c|}{ Traps - Monte Olimpo } & \multirow{2}{*}{ Total } & \multirow{2}{*}{$(\%)$} \\
\hline & 1 & 2 & 3 & 4 & 5 & 6 & 7 & & & 8 & 9 & 10 & 11 & 12 & 13 & 14 & & \\
\hline A. amita & 1 & 0 & 0 & 1 & 0 & 0 & 0 & 2 & 0.19 & 0 & 1 & 0 & 0 & 1 & 1 & 2 & 5 & 0.92 \\
\hline A. barbiellinii & 0 & 0 & 5 & 1 & 22 & 2 & 0 & 30 & 2.88 & 0 & 1 & 0 & 8 & 0 & 0 & 3 & 12 & 2.22 \\
\hline A. bistrigata & 1 & 1 & 0 & 4 & 4 & 3 & 2 & 15 & 1.44 & 13 & 1 & 1 & 0 & 0 & 1 & 0 & 16 & 2.96 \\
\hline A. daciformis & 1 & 0 & 0 & 0 & 4 & 0 & 0 & 5 & 0.48 & 0 & 0 & 0 & 0 & 0 & 0 & 0 & $\mathbf{0}$ & 0 \\
\hline A. distincta & 0 & 0 & 1 & 0 & 0 & 0 & 0 & 1 & 0.10 & 1 & 0 & 0 & 0 & 0 & 0 & 0 & 1 & 0.18 \\
\hline A. fraterculus & 31 & 64 & 315 & 79 & 47 & 54 & 101 & 691 & 66.38 & 201 & 5 & 41 & 110 & 6 & 5 & 58 & 426 & 78.6 \\
\hline A. grandis & 0 & 0 & 0 & 0 & 0 & 0 & 0 & $\mathbf{0}$ & 0 & 2 & 0 & 0 & 0 & 0 & 0 & 0 & 2 & 0.37 \\
\hline A. manihoti & 1 & 1 & 1 & 0 & 3 & 0 & 0 & 6 & 0.58 & 0 & 0 & 1 & 0 & 0 & 0 & 0 & 1 & 0.18 \\
\hline A. montei & 0 & 0 & 2 & 0 & 2 & 0 & 0 & 4 & 0.38 & 0 & 0 & 1 & 0 & 0 & 0 & 0 & 1 & 0.18 \\
\hline A. obliqua & 18 & 28 & 11 & 9 & 5 & 1 & 9 & 81 & 7.78 & 6 & 1 & 20 & 1 & 0 & 0 & 0 & 28 & 5.17 \\
\hline A. pickeli & 4 & 0 & 1 & 0 & 3 & 0 & 0 & 8 & 0.77 & 0 & 0 & 0 & 1 & 0 & 0 & 0 & 1 & 0.18 \\
\hline A. pseudoparallela & 3 & 3 & 19 & 0 & 4 & 100 & 69 & 198 & 19.02 & 1 & 6 & 0 & 4 & 0 & 1 & 34 & 46 & 8.49 \\
\hline A. serpentina & 0 & 0 & 0 & 0 & 0 & 0 & 0 & $\mathbf{0}$ & 0 & 0 & 0 & 1 & 0 & 0 & 0 & 0 & 1 & 0.18 \\
\hline A. sororcula & 0 & 0 & 0 & 0 & 0 & 0 & 0 & $\mathbf{0}$ & 0 & 1 & 0 & 0 & 0 & 0 & 0 & 1 & 2 & 0.37 \\
\hline Total & 60 & 97 & 355 & 94 & 94 & 160 & 181 & 1041 & & 225 & 15 & 65 & 124 & 7 & 8 & 98 & 542 & \\
\hline
\end{tabular}

\section{Overlap patterns}

The overlapping simulations based on the null model (Rosario randomization) using relative abundance data for both areas showed that all values were significantly higher than expected at random. For Fazenda Areão, the Pianka and Czechanowski indices were lower than 0.002 (Appendix 3), and for the Monte Olimpo area, the values were lower than 0.03 (Appendix 2).

For the analyses with abundance data, the observed means were 0.21665 for Fazenda Areão and 0.111108 for Monte Olimpo. For the simulated means of the indices, of the 1,000 simulated niche overlays for each area, the values obtained were 0.12942 and 0.07146 for Fazenda Areão and Monte Olimpo, respectively. The mean overlap was significantly higher than expected at random for both Fazenda Areão $(\mathrm{p}<0.000)$ and Monte Olimpo $(\mathrm{p}<0.008)$.

\section{Co-occurrence patterns}

There was variation in the number of species found in each area (11 in Fazenda Areão and 13 in Monte Olimpo). The abundance data analyses indicated that the co-occurrence pattern, based on the IT randomization algorithm, diverged between the two areas, except for the Andof pattern (Table 3). At Fazenda Areão, the high $\mathrm{C}$-score value suggests that the pairs of species were more segregated than expected. At Monte Olimpo this value was negative, so the pairs of species were more aggregate than expected. The negative NODF value for Fazenda Areão reveals overall patterns of antinestedness, with the opposite occurring at Monte Olimpo (which had a positive value).

Based on the analysis of presence-absence data, 5 pairs of significant species (3 aggregated and 2 segregated) were obtained for the two areas.

Correlation of the population fluctuations of the pairs showed that the species composing each aggregate pair had peaks occurring in the same period. However, with the segregated pairs the opposite occurred, i.e., when one population had a strong population increase, the population level of the other was small (Figures 2 and 3).

At Fazenda Areão, three pairs of non-random species occurred: A. pseudoparallela $\times$ A. obliqua 
(Figure 4), A. bistrigata $\times A$. montei, and A. fraterculus $\times$ A. barbiellinii; the first pair was segregated while the others were aggregated (Table 4). At Monte Olimpo, two pairs of non-random species were found: $A$. fraterculus $\times$ A. bistrigata and $A$. fraterculus $\times$ A. pseudoparallela. There was aggregation in the first pair and segregation in the second pair (Table 4). In these analyses, boxplots use data in which both species occur together or separately and their relationships with temperature and the day of collection.
TABLE 3: Values of the presence-absence matrix (C-score and NODF) by the fixed-fixed null model, and abundance matrix (Checker and Andof) by the null IT model of Anastrepha species at Fazenda Areão and Monte Olimpo (MO), campus "Luiz de Queiroz", ESALQ / USP, Piracicaba, SP, from July 1998 to June 1999

\begin{tabular}{ccccc}
\hline \multirow{2}{*}{ Areas } & \multicolumn{2}{c}{$\begin{array}{c}\text { Presence-absence } \\
\text { matrix }\end{array}$} & \multicolumn{2}{c}{ Abundance matrix } \\
\cline { 2 - 5 } & C-score & NODF & Checker & Andof \\
\hline Fazenda Areão & 3.23 & -2.48 & 4.77 & -4.91 \\
Monte Olimpo & -4.38 & 6.62 & -4.64 & -4.01 \\
\hline
\end{tabular}

FIGURE 2: Population fluctuation of aggregate pairs A. fraterculus x A. barbiellinii and A. montei x A. bistrigata and segregated pair $A$. pseudoparallela x A. obliqua, Fazenda Areão, "Luiz de Queiroz" campus, ESALQ, Piracicaba, SP, from July 1998 to June 1999.
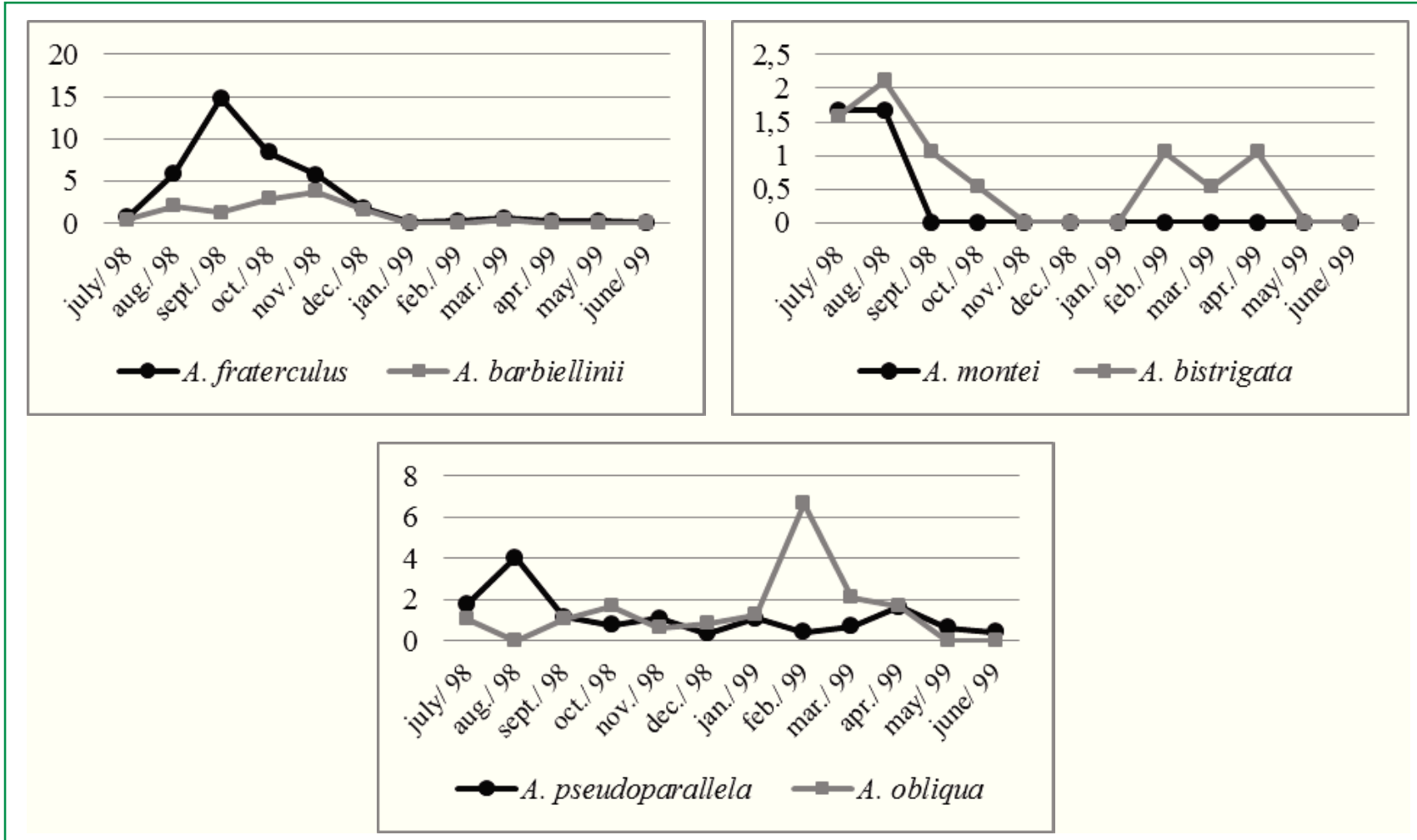
FIGURE 3: Population fluctuation of the aggregate pair A. fraterculus x A. bistrigata and the segregated pair A. fraterculus x A. pseudoparallela, at Monte Olimpo, “Luiz de Queiroz” campus, ESALQ, Piracicaba, SP, from July 1998 to June 1999.

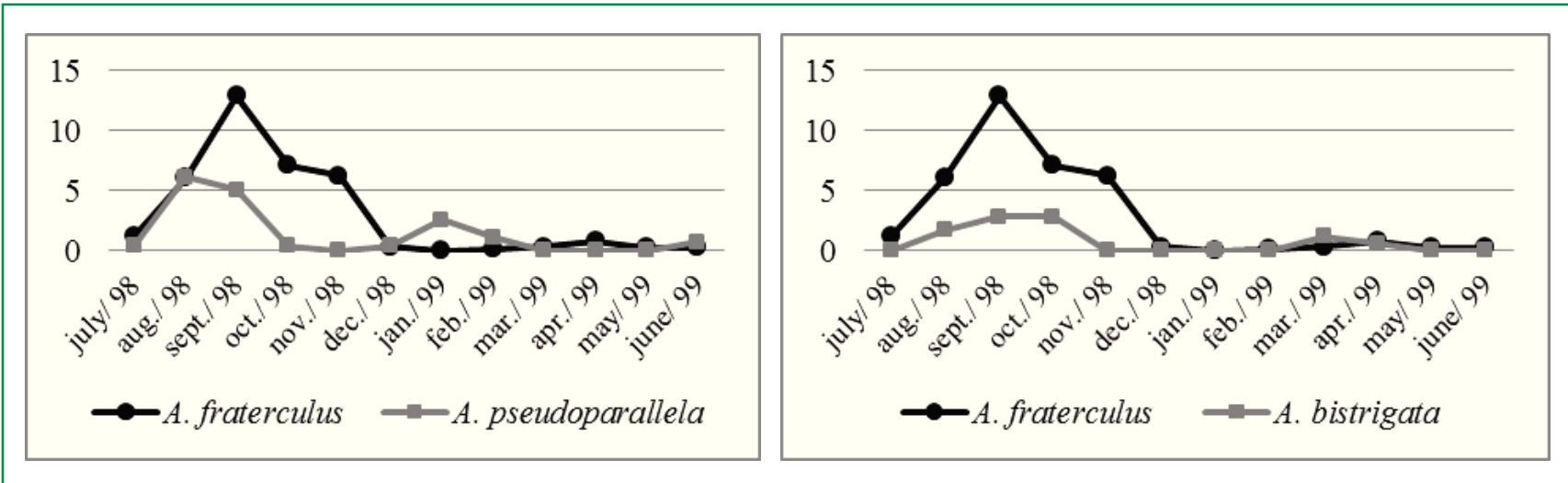

FIGURE 4: Pattern of co-occurrence based on presence-absence data at Fazenda Areão, Campus "Luiz de Queiroz", ESALQ, Piracicaba, SP, from July 1998 to June 1999. Segregated pair: A. pseudoparallela (Ap) x A. obliqua (Ao).

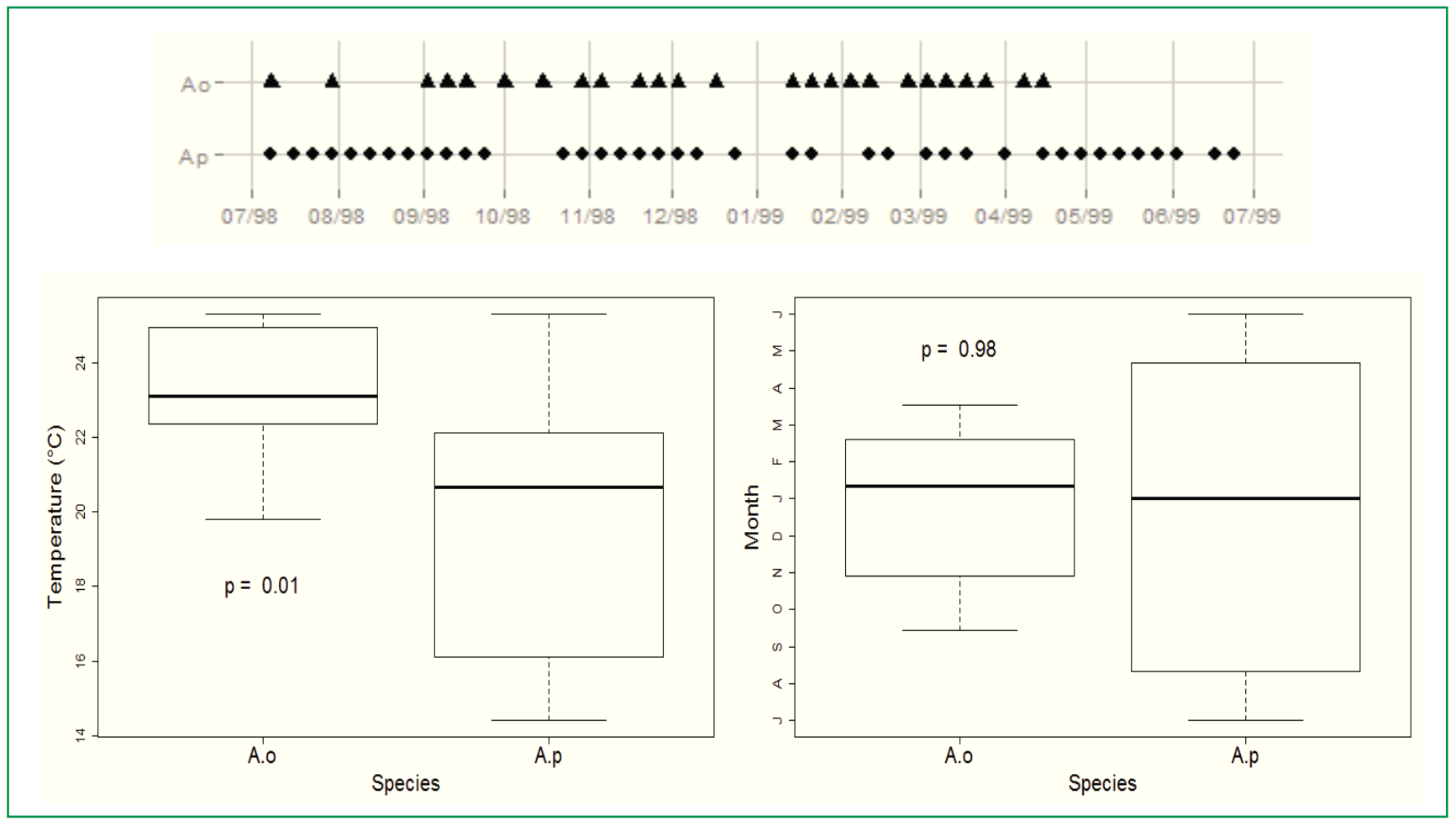


TABLE 4: Pattern of co-occurrence of significant pairs of fruit fly species analyzed by the fixed-fixed null model algorithm at Fazenda Areão (F.A.) and at Monte Olimpo (M.O.), campus "Luiz de Queiroz", USP, Piracicaba, SP, from July 1998 to June 1999

Pairs of species

$\begin{array}{llllllllllll}07 / 98 & 08 / 98 & 09 / 98 & 10 / 98 & 11 / 98 & 12 / 98 & 01 / 99 & 02 / 99 & 03 / 99 & 04 / 99 & 05 / 99 & 06 / 99\end{array}$

Fazenda Areão

A. pseudoparallela x A. obliqua

A. montei x $A$. bistrigata

A. fraterculus x A. barbiellinii

$\begin{array}{ll}- & - \\ + & + \\ + & +\end{array}$

Monte Olimpo

A. fraterculus $\mathrm{x} A$. bistrigata

$+\quad+\quad+$

A. fraterculus x $A$. pseudoparallela

\begin{tabular}{l}
- \\
\hline
\end{tabular}

\section{Discussion}

\section{Anastrepha species}

Considering that the abiotic factors are practically the same throughout the campus, it can be inferred that the Anastrepha species were influenced exclusively by host availability.

At Fazenda Areão, trap 3, where more Anastrepha females were collected, was located in an area with several host plants (passion fruit, coffee, mango and loquat). On the other hand, the smallest number of specimens were captured in trap 1 (mango orchard), but among these species only $A$. fraterculus and $A$. obliqua attack the mango. At Monte Olimpo, trap 8 was installed in an area with several hosts (cashew, persimmon, pitanga, jabuticaba, guava, citrus and acerola), and more specimens were collected (ZUCCHI, 2008). In trap 12, although it was hung in a site with citrus plants, few specimens were captured; similar results were obtained for trap 13, which was hung in a site without fruit fly hosts.

The host diversity favored the maintenance of fruit fly populations in the two anthropic areas. Nonhost plants may serve as shelter and resting sites for fruit flies, since the type of vegetation at the trapping site significantly influences the number of specimens collected (VARGAS et al., 1990).
Ecosystem anthropization can favor the evolution and adaptation of fruit fly species, which may then associate with new hosts (RAGA et al., 2011). Environmental modification and consequent removal of the vegetation causes greater negative impacts on monophagous species.

At Monte Olimpo, which has a less altered landscape and therefore a greater variety of native plants, the traps were hung near 11 host plants, including native species. At Fazenda Areão, the traps were installed near seven host plants, including native species. The availability of fruiting hosts throughout the sample period was the main factor contributing to the maintenance $A$. fraterculus in both areas. Therefore, the dominance of this species is probably due to the ability to develop in many host species.

Passion fruit occurred in only one site (trap 3); however, A. pseudoparallela, which develops preferentially in this host, was also captured in the other collection points. Therefore, the relatively high abundance of this specialist species in the collections indicates that in the vicinity of the collection points, Passifloraceae should also occur.

The landscape in the vicinity of the study area is composed of a residential neighborhood; thus, the host plants present in residences also contribute to the maintenance of fruit flies in the area. In addition, the 
large fluctuations in the fruit fly populations can be minimized by the presence of alternative hosts (ALUJA, 1994).

The aforementioned factors may have also influenced the diversity of the species collected. At Fazenda Areão, 35\% of the A. obliqua specimens were collected in trap 2 (citrus area) and $22 \%$ in trap 1 (mango area), with the latter expected to collect more individuals of this species. However, there may have been interference in the collection due to the proximity of these traps and the presence of mango (the preferred host) at the site of trap 3.

Anastrepha fraterculus was more abundant in areas with high host diversity in both areas. The occurrence of A. pseudoparallela at Monte Olimpo was likely due to the presence of passion fruit (preferred host) near this area.

\section{Overlap pattern}

The simulation based on overall and relative abundance data indicated that the observed mean niche overlap was significantly higher than expected at random for both areas. Thus, the ecological niches of species largely overlap. Although null models can be used to establish whether the observed niche overlap is greater or less than expected at random, it is still difficult to infer the mechanisms responsible for such patterns (GOTELLI; GRAVES, 1996). Despite the different host composition in the two areas, it can be inferred that host diversity did not influence niche overlap. Regardless, host diversity and the proximity of the sites (approximately $4 \mathrm{~km}$ ) should also be considered when evaluating niche overlap since fruit flies can fly long distances.

Although the mechanisms underlying competition are poorly understood, these mechanisms may be specific for each pair of competing species. In the case of tephritids, niche overlap can occur as a result of competition because competitive interactions can result in either ecological displacement (i.e., one or both species moving or reducing their niche until coexistence becomes possible) or competitive exclusion of one or more species (DUYCK et al., 2004; LOPES et al.,
2015). The pattern of overlap of Anastrepha species in Piracicaba was similar to that found in Monte Alegre do Sul, SP, in a study where the simulation also produced values that were significantly higher than expected at random (LOPES et al., 2015).

The simulations carried out indicated that the patterns of the two areas were divergent, with pairs of species more segregated than expected and overall patterns of anti-nestedness at Fazenda Areão and more aggregate than expected for Monte Olimpo.

For the two areas, two pairs of non-random species that segregated, A. pseudoparallela x A. obliqua in Fazenda Areão and A. fraterculus x A. pseudoparallela in Monte Olimpo, indicated that there is interspecific competition for either resource or space within the niche. Considering the development of $A$. pseudoparallela (a specialist) in passion fruit, it can be assumed that the segregation of this species with A. fraterculus (a generalist) was due to the exploitation of this host, since A. fraterculus also occurs in passion fruit. However, the mechanisms for segregation between $A$. pseudoparallela and $A$. obliqua are not clear. Although A. obliqua is a generalist species, it does not attack passion fruit, the host preferred by $A$. pseudoparallela. It is likely that this segregation is related to differences in the availability of the preferred hosts of these species when compared to Monte Olimpo. Anastrepha pseudoparallela also segregated with $A$. obliqua, A. sororcula and $A$. bistrigata in a loquat orchard (LOPES et al., 2015).

The analysis also presented three aggregate pairs: A. bistrigata $\mathrm{x}$ A. montei, A. fraterculus $\mathrm{x}$ A. barbiellinii (Fazenda Areão) and $A$. fraterculus x $A$. bistrigata (Monte Olimpo). Therefore, there seems to be no competition for resource or space, and each pair cooccurs naturally without interfering with the permanence of the populations. The aggregate co-occurrence of the two pairs of species in Fazenda Areão (A. bistrigata x $A$. monte $i$ and $A$. fraterculus $\mathrm{x}$ A. barbiellinii) is likely due to the specific exploitation of plant hosts, mainly by the specialists $A$. montei and $A$. barbiellinii, which develop in Euphorbiaceae and Cactaceous hosts, respectively; these hosts are not exploited by A. bistrigata and A. fraterculus. At Monte Olimpo, the aggregate cooccurrence of $A$. fraterculus and A. bistrigata is a 
consequence of the high availability of guava, the preferred host of $A$. bistrigata, and also the potential of A. fraterculus (a polyphagous species) to exploit other hosts in the area in addition to guava.

Correlation of the population fluctuations of the aggregate pairs in Fazenda Areão showed that $A$. montei x A. bistrigata showed the highest population indices in August. However, there is no record of these species exploiting similar hosts, since $A$. montei prefers Euphorbiaceae hosts, which are not hosts of A. bistrigata; thus, host competition between these species is unlikely. In addition, because populations of these species were small, competition for space is also minimized. These two factors favor peaceful cooccurrence between $A$. montei and A. bistrigata. In the pair formed by $A$. fraterculus x $A$. barbiellinii, there is also no competition for hosts since the only known host of $A$. barbiellinii is a Cactaceae species of the genus Pereskia (ZUCCHI, 2008). Further, the population peak of this species occurred in November while the peak for A. fraterculus occurred in September. Although the population decreased in November, there was still a large population of $A$. fraterculus in the area due to the diversity of hosts exploited by this species.

At Monte Olimpo, there was a single aggregate pair: A. bistrigata $\mathrm{x}$ A. fraterculus. Among the hosts of A. bistrigata, only guava was found in the area. In trap 8, which was located in a site with guava, $81 \%$ of the total specimens of this species were collected. However, the highest occurrence of these species was from September to October (Figure 3), a period without guava. The $A$. bistrigata population probably utilized guava outside of the area. The aggregate co-occurrence of these two species may have been due to the low population of A. bistrigata, reducing the competitive pressure on the $A$. fraterculus population. Aggregations among $A$. fraterculus, A. striata and Bactrocera carambolae were recently observed in guava in eastern Amazonia. These interactions followed a negative binomial distribution pattern, suggesting that the species coexist in that region (DEUS et al., 2016).

In the Fazenda Areão, the segregated pair $A$. pseudoparallela x A. obliqua showed population peaks in August 1998 and February 1999, respectively. During the population peak of $A$. pseudoparallela, no A. obliqua specimens were collected, probably due to the presence of passion fruit, which is not attacked by A. obliqua. However, considering that these species do not exploit the same hosts, they were expected to co-occur in the environment.

At Monte Olimpo, segregation occurred between $A$. fraterculus and A. pseudoparallela. The first population peak of A. pseudoparallela occurred in August, followed by a sharp fall in the following two months when there was a large population increase of $A$. fraterculus. In the second peak, specimens of $A$. pseudoparallela and $A$. fraterculus were not collected. Competition between these pairs can be attributed to host competition, because although passion fruit is preferred by A. pseudoparallela, it can also be attacked by $A$. fraterculus.

Although it has not been evaluated, the possibility of competition with other species of fruit flies like the exotic species Ceratitis capitata cannot be ruled out. Through aggressive behavior, exotic species can displace native populations or exclude them from the niche (GOTELLI; GRAVES, 1996). In a co-occurrence study conducted in Monte Alegre do Sul, C. capitata exerted pressure on the populations of Anastrepha, presenting segregation with several species of Anastrepha (LOPES et al., 2015). Ceratitis capitata is widespread throughout Brazil and developing in 92 hosts (ZUCCHI, 2012), and in some areas this species has displaced Anastrepha species (ARAUJO et al., 2000).

Our results show that the ecological niches of Anastrepha species overlap in the two anthropic areas of the "Luiz de Queiroz" campus. In Fazenda Areão, there is aggregation in the pairs $A$. bistrigata $\mathrm{x} A$. montei and $A$. fraterculus $\mathrm{x} A$. barbiellinii and segregation between $A$. pseudoparallela $\times A$. obliqua. At Monte Olimpo, segregation occurred between $A$. fraterculus $\mathrm{x}$ A. pseudoparallela while A. fraterculus x A. bistrigata were aggregated.

\section{References}

ALEXANDRINO, E. R.; BOVO, A. A. A.; LUZ, D. T. A.; COSTA, J. C.; BETINI, G. S.; FERRAZ, K. M. P. M. B.; COUTO, H. T. Z. Aves do campus "Luiz de Queiroz" (Piracicaba, SP) da 
Universidade de São Paulo: mais de 10 anos de observações neste ambiente antrópico. Atualidades Ornitológicas On-line, Ivaiporã, n. 173, 2013.

ALUJA, M.; Bionomics and management of Anastrepha. Annual Review of Entomology, Palo Alto, v. 39, p. 155-178, 1994.

ARAUJO, E. L.; LIMA, F. A. M.; ZUCCHI, R. A. Moscas-dasfrutas nos estados brasileiros. Rio Grande do Norte.In: MALAVASI, A.; ZUCCHI, R. A. (Ed.). Moscas-das-frutas de importância econômica no Brasil: conhecimento básico e aplicado. São Paulo: Holos, 2000. p. 223-226.

BEGON, M.; HARPER, J. L.; TOWNSEND, C. R. Ecology: individuals, populations and communities. 3. ed. Oxford: Blackwell Science, 1996. 1068 p.

CASTRO-ARELLANO, I.; LACHER JR, T. E.; WILLIG, M. R.; RANGEL, T. F. Assessment of assemblage-wide temporal niche segregation using null models. Methods in Ecology and Evolution, London, v. 1, n. 3, p. 311-318, 2010.

DEUS, E. G.; GODOY, W. A. C.; SOUSA, M. S. M.; LOPES, G. N.; JESUS-BARROS, C. R.; SILVA, J. G.; ADAIME, R. Coinfestation and spatial distribution of Bactrocera carambolae and Anastrepha spp. (Diptera: Tephritidae) in common guava in the eastern amazon. Journal of Insect Science, Madison, v. 16, n. 1, p. 1-7, 2016.

DIAMANTIDIS, A. D.; CAREY, J. R.; NAKAS, C. T.; PAPADOPOULOS, N. T. Population-specific demography and invasion potential in medfly. Ecology and Evolution, Sheffield, v. 1, n. 4, p. 479-88, 2011.

DUYCK, P. F.; DAVID, P.; QUILICI, S. A review of relationships between interspecific competition and invasions in fruit flies (Diptera: Tephritidae). Ecological Entomology, London, v. 29, n. 5, p. 511-520, 2004.

EKK, I.; KISS, M.; NOWINSZKY, L.; SZABO, S.; TOTH, G. The coefficient of population and its application in plant-protecting prognosis. Folia Entomologica Hungarica, Budapest, v. 33, n. 2 , p. 23-32, 1980.

FEINSINGER, P.; SPEARS, E. E.; POOLE, R. W. A simple measure of niche breadth. Ecology, New York, v. 62, n. 1, p. 27-32, 1981.

FITT, G. P. The role of interspecific interactions in the dynamics of tephritid populations. In: ROBINSON, A. S.; HOOPER, G. (Ed.). Fruit flies, their biology, natural enemies and control. Amsterdam: Elsevier, 1989. p. 281-300.

GOTELLI, N. J. Null model analysis of species co-occurrence patterns. Ecology, New York, v. 81, p. 2606-2621, 2000.

GOTELLI, N. J.; ELLISON, A. M. EcoSimR 1.00. 2013. Available in: $\quad<$ http://www.uvm.edu/ ngotelli/EcoSim/EcoSim.html $>$. Accessed on: 15 September 2016.

GOTELli, N. J.; ENTSMINGER, G. L. EcoSim 7.72. 2012. Acquired Intelligence, Inc. Available in: <http://www.uvm. edu/ ngotelli/EcoSim/EcoSim.html $>$. Accessed on: 08 September 2016.
GOTElli, N. J.; GRAVES, G. R. Null models in Ecology. Washington: Smithsonian Institution Press, 1996. 368 p.

LOPES, G. N.; SOUZA-FILHO, M. F.; GOTELLI, N. J.; LEMOS, L. J. U.; GODOY, W. A. C.; ZUCCHI, R. A. Temporal Overlap and Co-Occurrence in a Guild of Sub-Tropical Tephritid Fruit Flies. PLoS ONE, Cambridge, v. 10, n. 7, e0132124, 2015.

R CORE TEAM. R: A language and environment for statistical computing. Vienna: R Foundation for Statistical Computing, 2013. Available in: <http://www.R-project.org/>. Accessed on: 15 September 2016.

RAGA, A.; SOUZA-FILHO, M. F.; MACHADO, R. A.; SATO, M. E.; SILOTO, R. C. Host ranges and infestation indices of fruit flies (Tephritidae) and lances flies (Lonchaeidae) in São Paulo state, Brazil. Florida Entomologist, Lutz, v. 94, n. 4, p.787-794, 2011.

ROITBERG, B. D.; PROKOPY, R. J. Insects that mark host plants. Bioscience Journal, Oxford, v. 37, n. 6, p. 400-406, 1987.

ULRICH W. CoOccurrence: a FORTRAN program for species co-occurrence analysis. 2006. Available in: <www.uni.torun. pl/ ulrichw>. Accessed on: 15 September 2016.

ULRICH W. Pairs: a FORTRAN program for studying pair-wise species associations in ecological matrices. 2008. Available in: $<$ www.uni.torun.pl/ ulrichw>. Accessed on: 15 September 2016.

ULRICH, W., GOTELLI, N. J. Null model analysis of species associations using abundance data. Ecology, New York, v. 91, p. 3384-3397, 2010.

URAMOTO, K.; WALDER, J. M. M.; ZUCCHI, R. A. Flutuação populacional de moscas-das-frutas do gênero Anastrepha Schiner, 1868 (Diptera, Tephritidae) no campus "Luiz de Queiroz", Piracicaba, São Paulo. Arquivos do Instituto Biológico, São Paulo, v. 4, n. 70, p. 459-465, 2003.

URAMOTO, K.; WALDER, J. M. M.; ZUCCHI, R. A. Biodiversidade de moscas-das-frutas do gênero Anastrepha (Diptera, Tephritidae) no campus da ESALQ-USP, Piracicaba, São Paulo. Revista Brasileira de Entomologia, Curitiba, v. 3, n. 48, p. 409-414, 2004.

VARGAS, R. I.; STARK, J. D.; NISHIDA, T. Population dynamics, habitat preference, and seasonal distribution patterns of oriental fruit fly and melon fly (Diptera: Tephritidae) in an agricultural area. Environmental Entomology, Lanham, v. 19, n. 6, p. 18201828, 1990.

ZUCCHI, R. A. Fruit flies in Brazil - Anastrepha species their host plants and parasitoids. 2008. Available in $<$ www.lea.esalq.usp. br/anastrepha/>. Accessed on: 20 September 2016.

ZUCCHI, R. A. Fruit flies in Brazil - Hosts and parasitoids of the Mediterranean fruit fly. 2012. Available in: <www.lea.esalq.usp.br/ ceratitis. Accessed on: 18 September 2016. 


\section{APPENDIX 1:}

Average collection day temperature in "Luiz de Queiroz" campus, USP, Piracicaba, SP, from July 1998 to June 1999.

\begin{tabular}{cccccc}
\hline $\begin{array}{c}\text { Collection } \\
\text { date }\end{array}$ & $\begin{array}{c}\text { Average } \\
\text { temperature }\left({ }^{\mathbf{o}} \mathbf{C}\right)\end{array}$ & $\begin{array}{c}\text { Collection } \\
\text { date }\end{array}$ & $\begin{array}{c}\text { Average } \\
\text { temperature }\left({ }^{\circ} \mathbf{C}\right)\end{array}$ & $\begin{array}{c}\text { Collection } \\
\text { date }\end{array}$ & $\begin{array}{c}\text { Average } \\
\text { temperature }\left({ }^{\circ} \mathbf{C}\right)\end{array}$ \\
\hline $02 / 07$ & 18.5 & $05 / 11$ & 23.7 & $11 / 03$ & 22.3 \\
$08 / 07$ & 19.7 & $12 / 11$ & 21.0 & $18 / 03$ & 24.5 \\
$16 / 07$ & 15.8 & $19 / 11$ & 20.4 & $25 / 03$ & 24.9 \\
$23 / 07$ & 18.9 & $26 / 11$ & 24.2 & $01 / 04$ & 25.3 \\
$30 / 07$ & 16.4 & $03 / 12$ & 27.6 & $08 / 04$ & 22.1 \\
$06 / 08$ & 16.0 & $10 / 12$ & 24.0 & $15 / 04$ & 22.0 \\
$13 / 08$ & 23.6 & $17 / 12$ & 23.0 & $22 / 04$ & 25.9 \\
$20 / 08$ & 22.1 & $24 / 12$ & 20.8 & $29 / 04$ & 24.4 \\
$27 / 08$ & 20.4 & $31 / 12$ & 24.9 & $06 / 05$ & 23.8 \\
$03 / 09$ & 22.0 & $07 / 01$ & 20.6 & $13 / 05$ & 23.4 \\
$10 / 09$ & 18.6 & $14 / 01$ & 23.8 & $20 / 05$ & 23.3 \\
$17 / 09$ & 23.7 & $21 / 01$ & 27.6 & $27 / 05$ & 23.2 \\
$24 / 09$ & 20.5 & $28 / 01$ & 25.0 & $03 / 06$ & 24.5 \\
$01 / 10$ & 19.8 & $04 / 02$ & 25.3 & $10 / 06$ & 25.6 \\
$08 / 10$ & 20.2 & $11 / 02$ & 23.1 & $17 / 06$ & 24.2 \\
$15 / 10$ & 22.6 & $18 / 02$ & 25.1 & $24 / 06$ & 22.6 \\
$22 / 10$ & 22.9 & $25 / 02$ & 23.2 & & \\
$29 / 10$ & 22.4 & $04 / 03$ & 23.9 & & \\
\hline
\end{tabular}

\section{APPENDIX 2:}

Anastrepha species caught in McPhail traps in Monte Olimpo area, "Luiz de Queiroz" campus, USP, Piracicaba, SP, from july 1998 to june 1999.

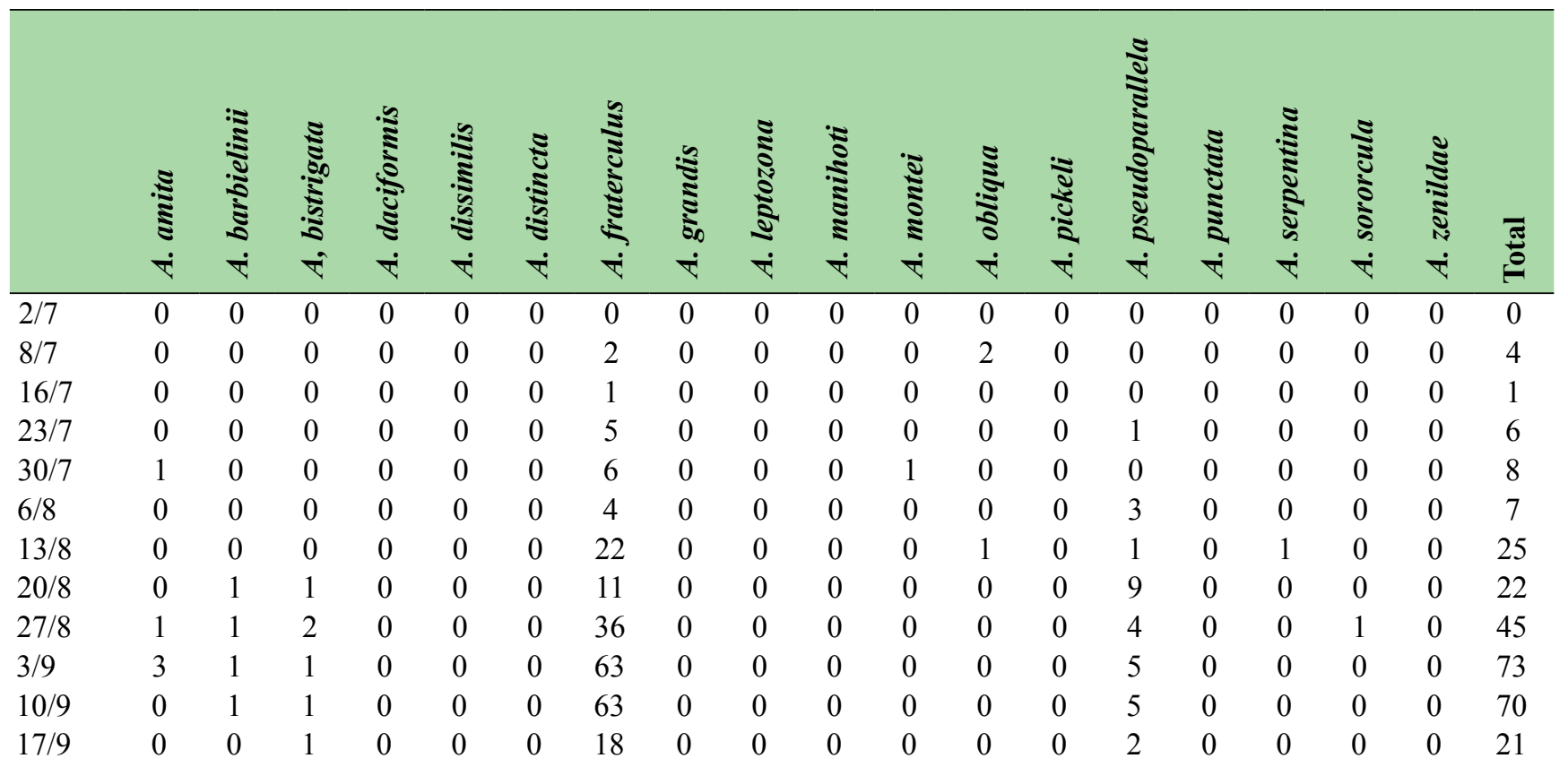


$\begin{array}{llllllllllllllllllll}24 / 9 & 0 & 0 & 2 & 0 & 0 & 0 & 11 & 0 & 0 & 0 & 0 & 0 & 0 & 2 & 0 & 0 & 0 & 0 & 15\end{array}$

$\begin{array}{llllllllllllllllllll}1 / 10 & 0 & 0 & 1 & 0 & 0 & 0 & 17 & 0 & 0 & 0 & 0 & 0 & 0 & 0 & 0 & 0 & 0 & 0 & 18\end{array}$

$\begin{array}{llllllllllllllllllll}8 / 10 & 0 & 0 & 2 & 0 & 0 & 0 & 30 & 0 & 0 & 0 & 0 & 4 & 0 & 1 & 0 & 0 & 0 & 0 & 37\end{array}$

$15 / 10 \quad 00 \begin{array}{llllllllllllllllll}14\end{array}$

$\begin{array}{llllllllllllllllllll}22 / 10 & 0 & 0 & 0 & 0 & 0 & 0 & 12 & 0 & 0 & 0 & 0 & 0 & 0 & 0 & 0 & 0 & 0 & 0 & 12\end{array}$

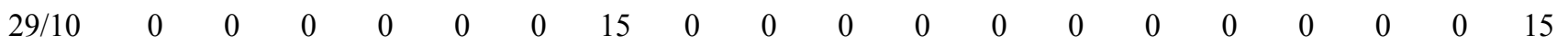

$\begin{array}{llllllllllllllllllll}5 / 11 & 0 & 1 & 0 & 0 & 0 & 0 & 20 & 0 & 0 & 0 & 0 & 0 & 0 & 0 & 0 & 0 & 0 & 0 & 21\end{array}$

$\begin{array}{llllllllllllllllllll}12 / 11 & 0 & 1 & 0 & 0 & 0 & 0 & 38 & 0 & 0 & 0 & 0 & 0 & 0 & 0 & 0 & 0 & 0 & 0 & 39\end{array}$

$\begin{array}{llllllllllllllllllll}19 / 11 & 0 & 1 & 0 & 0 & 0 & 0 & 8 & 0 & 0 & 0 & 0 & 3 & 0 & 0 & 0 & 0 & 0 & 0 & 12\end{array}$

$\begin{array}{llllllllllllllllllll}26 / 11 & 0 & 2 & 0 & 0 & 0 & 0 & 9 & 0 & 0 & 0 & 0 & 0 & 1 & 0 & 0 & 0 & 0 & 0 & 12\end{array}$

$\begin{array}{llllllllllllllllllll}3 / 12 & 0 & 1 & 0 & 0 & 0 & 0 & 3 & 0 & 0 & 0 & 0 & 3 & 0 & 0 & 0 & 0 & 0 & 0 & 7\end{array}$

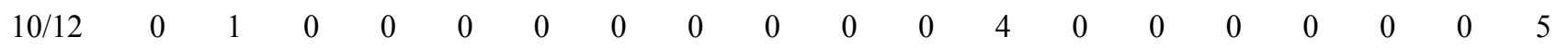

$\begin{array}{lllllllllllllllllllll}17 / 12 & 0 & 0 & 0 & 0 & 0 & 0 & 0 & 0 & 0 & 0 & 0 & 3 & 0 & 1 & 0 & 0 & 0 & 0 & 4\end{array}$

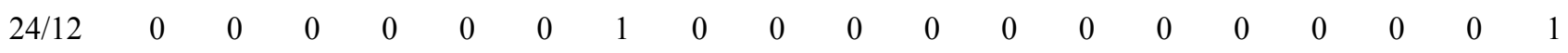

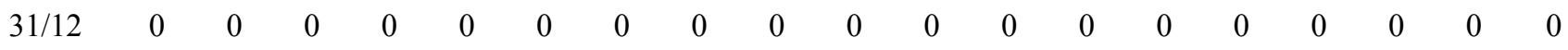

$\begin{array}{llllllllllllllllllll}7 / 1 & 0 & 0 & 0 & 0 & 0 & 0 & 0 & 0 & 0 & 0 & 0 & 0 & 0 & 0 & 0 & 0 & 0 & 0 & 0\end{array}$

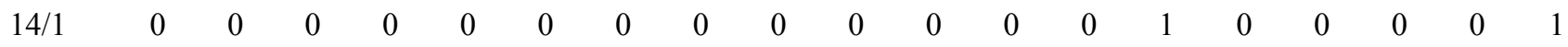

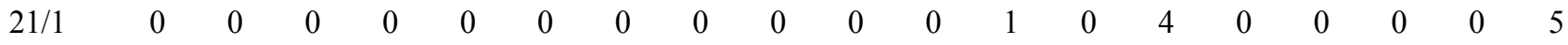

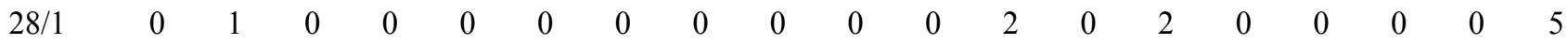

$\begin{array}{llllllllllllllllllll}4 / 2 & 0 & 0 & 0 & 0 & 0 & 0 & 0 & 0 & 0 & 0 & 0 & 0 & 0 & 1 & 0 & 0 & 0 & 0 & 1\end{array}$

$\begin{array}{llllllllllllllllllll}11 / 2 & 0 & 0 & 0 & 0 & 0 & 0 & 0 & 0 & 0 & 1 & 0 & 0 & 0 & 1 & 0 & 0 & 0 & 0 & 2\end{array}$

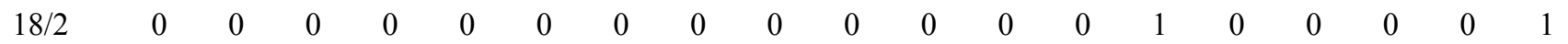
$\begin{array}{llllllllllllllllllll}25 / 2 & 0 & 0 & 0 & 0 & 0 & 1 & 1 & 0 & 0 & 0 & 0 & 0 & 0 & 0 & 0 & 0 & 0 & 0 & 2\end{array}$ $\begin{array}{llllllllllllllllllll}4 / 3 & 0 & 0 & 0 & 0 & 0 & 0 & 0 & 0 & 0 & 0 & 0 & 0 & 0 & 0 & 0 & 0 & 0 & 0 & 0\end{array}$ $\begin{array}{llllllllllllllllllll}11 / 3 & 0 & 0 & 0 & 0 & 0 & 0 & 0 & 0 & 0 & 0 & 0 & 0 & 0 & 0 & 0 & 0 & 0 & 0 & 0\end{array}$ $\begin{array}{llllllllllllllllllll}18 / 3 & 0 & 0 & 2 & 0 & 0 & 0 & 2 & 0 & 0 & 0 & 0 & 2 & 0 & 0 & 0 & 0 & 1 & 0 & 7\end{array}$ $\begin{array}{llllllllllllllllllll}25 / 3 & 0 & 0 & 0 & 0 & 0 & 0 & 2 & 0 & 0 & 0 & 0 & 1 & 0 & 0 & 0 & 0 & 0 & 0 & 3\end{array}$ $\begin{array}{llllllllllllllllllll}1 / 4 & 0 & 0 & 1 & 0 & 0 & 0 & 1 & 0 & 0 & 0 & 0 & 1 & 0 & 0 & 0 & 0 & 0 & 0 & 3\end{array}$

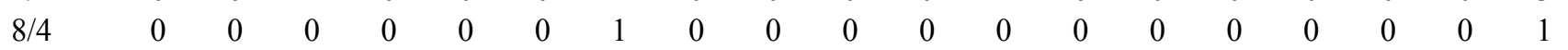

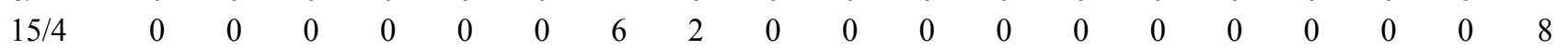

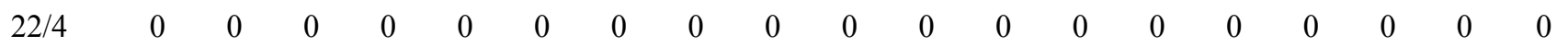

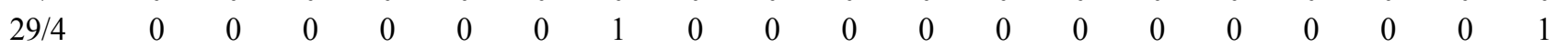

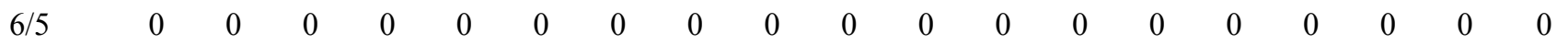

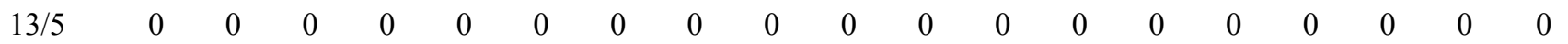

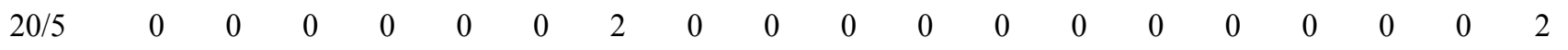

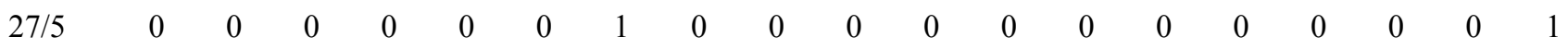
$\begin{array}{llllllllllllllllllll}3 / 6 & 0 & 0 & 0 & 0 & 0 & 0 & 0 & 0 & 0 & 0 & 0 & 0 & 0 & 0 & 0 & 0 & 0 & 0 & 0\end{array}$ $\begin{array}{llllllllllllllllllll}10 / 6 & 0 & 0 & 0 & 0 & 0 & 0 & 1 & 0 & 0 & 0 & 0 & 0 & 0 & 1 & 0 & 0 & 0 & 0 & 2\end{array}$ $\begin{array}{llllllllllllllllllll}17 / 6 & 0 & 0 & 0 & 0 & 0 & 0 & 0 & 0 & 0 & 0 & 0 & 0 & 0 & 1 & 0 & 0 & 0 & 0 & 1\end{array}$ \begin{tabular}{llllllllllllllllllll}
$24 / 6$ & 0 & 0 & 0 & 0 & 0 & 0 & 2 & 0 & 0 & 0 & 0 & 0 & 0 & 0 & 0 & 0 & 0 & 0 & 2 \\
\hline Total & $\mathbf{5}$ & $\mathbf{1 2}$ & $\mathbf{1 6}$ & $\mathbf{0}$ & $\mathbf{0}$ & $\mathbf{1}$ & $\mathbf{4 2 6}$ & $\mathbf{2}$ & $\mathbf{0}$ & $\mathbf{1}$ & $\mathbf{1}$ & $\mathbf{2 8}$ & $\mathbf{1}$ & $\mathbf{4 6}$ & $\mathbf{0}$ & $\mathbf{1}$ & $\mathbf{2}$ & $\mathbf{0}$ & $\mathbf{5 4 2}$ \\
\hline
\end{tabular} 


\begin{tabular}{|c|c|c|c|c|c|c|c|c|c|c|c|c|c|c|c|c|c|c|c|}
\hline & 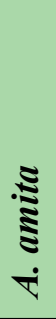 & 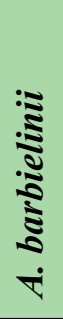 & 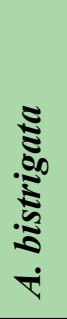 & 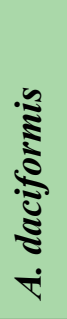 & 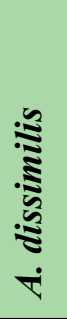 & 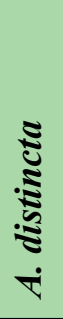 & 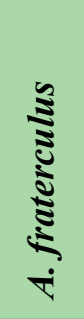 & 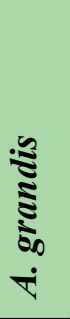 & 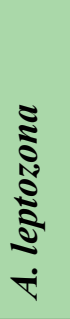 & 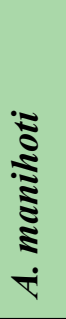 & 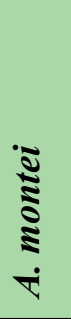 & 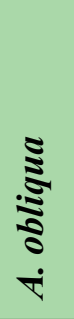 & 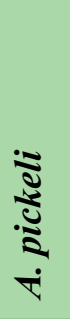 & 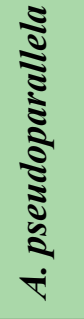 & 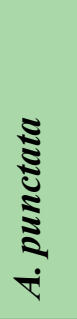 & 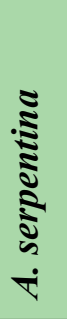 & 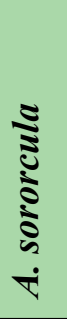 & 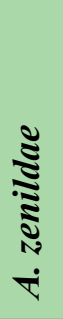 & $\stackrel{\bar{\pi}}{\tilde{\theta}}$ \\
\hline $2 / 7$ & 0 & 0 & 0 & 0 & 0 & 0 & 0 & 0 & 0 & 0 & 0 & 0 & 0 & 0 & 0 & 0 & 0 & 0 & 0 \\
\hline $8 / 7$ & 0 & 0 & 0 & 0 & 0 & 0 & 3 & 0 & 0 & 1 & 0 & 4 & 0 & 3 & 0 & 0 & 0 & 0 & 11 \\
\hline $16 / 7$ & 0 & 1 & 0 & 0 & 0 & 0 & 2 & 0 & 0 & 0 & 0 & 0 & 1 & 2 & 0 & 0 & 0 & 0 & 6 \\
\hline $23 / 7$ & 0 & 0 & 2 & 0 & 0 & 0 & 3 & 0 & 0 & 2 & 1 & 0 & 2 & 13 & 0 & 0 & 0 & 0 & 23 \\
\hline $30 / 7$ & 0 & 0 & 1 & 0 & 0 & 0 & 4 & 0 & 0 & 0 & 1 & 1 & 0 & 7 & 0 & 0 & 0 & 0 & 14 \\
\hline $6 / 8$ & 0 & 0 & 2 & 0 & 0 & 0 & 4 & 0 & 0 & 0 & 1 & 0 & 0 & 6 & 0 & 0 & 0 & 0 & 13 \\
\hline $13 / 8$ & 0 & 1 & 1 & 0 & 0 & 0 & 13 & 0 & 0 & 0 & 1 & 0 & 1 & 8 & 0 & 0 & 0 & 0 & 25 \\
\hline $20 / 8$ & 0 & 1 & 1 & 0 & 0 & 0 & 16 & 0 & 0 & 0 & 0 & 0 & 0 & 24 & 0 & 0 & 0 & 0 & 42 \\
\hline $27 / 8$ & 0 & 3 & 0 & 0 & 0 & 0 & 73 & 0 & 0 & 1 & 0 & 0 & 0 & 19 & 0 & 0 & 0 & 0 & 96 \\
\hline $3 / 9$ & 1 & 1 & 1 & 0 & 0 & 0 & 118 & 0 & 0 & 0 & 0 & 2 & 0 & 6 & 0 & 0 & 0 & 0 & 129 \\
\hline $10 / 9$ & 0 & 1 & 0 & 1 & 0 & 1 & 70 & 0 & 0 & 0 & 0 & 1 & 1 & 2 & 0 & 0 & 0 & 0 & 77 \\
\hline $17 / 9$ & 0 & 1 & 0 & 0 & 0 & 0 & 54 & 0 & 0 & 0 & 0 & 2 & 0 & 2 & 0 & 0 & 0 & 0 & 59 \\
\hline $24 / 9$ & 0 & 0 & 1 & 0 & 0 & 0 & 23 & 0 & 0 & 0 & 0 & 0 & 0 & 6 & 0 & 0 & 0 & 0 & 30 \\
\hline $1 / 10$ & 0 & 0 & 1 & 0 & 0 & 0 & 17 & 0 & 0 & 0 & 0 & 2 & 0 & 0 & 0 & 0 & 0 & 0 & 20 \\
\hline $8 / 10$ & 0 & 0 & 0 & 0 & 0 & 0 & 16 & 0 & 0 & 0 & 0 & 0 & 0 & 0 & 0 & 0 & 0 & 0 & 16 \\
\hline $15 / 10$ & 0 & 0 & 0 & 0 & 0 & 0 & 13 & 0 & 0 & 0 & 0 & 2 & 0 & 0 & 0 & 0 & 0 & 0 & 15 \\
\hline $22 / 10$ & 0 & 3 & 0 & 0 & 0 & 0 & 37 & 0 & 0 & 0 & 0 & 0 & 0 & 7 & 0 & 0 & 0 & 0 & 47 \\
\hline $29 / 10$ & 0 & 4 & 0 & 0 & 0 & 0 & 67 & 0 & 0 & 1 & 0 & 4 & 0 & 4 & 0 & 0 & 0 & 0 & 80 \\
\hline $5 / 11$ & 0 & 2 & 0 & 0 & 0 & 0 & 30 & 0 & 0 & 0 & 0 & 1 & 0 & 1 & 0 & 0 & 0 & 0 & 34 \\
\hline $12 / 11$ & 0 & 3 & 0 & 2 & 0 & 0 & 24 & 0 & 0 & 0 & 0 & 0 & 0 & 1 & 0 & 0 & 0 & 0 & 30 \\
\hline $19 / 11$ & 0 & 2 & 0 & 0 & 0 & 0 & 24 & 0 & 0 & 0 & 0 & 1 & 0 & 8 & 0 & 0 & 0 & 0 & 35 \\
\hline $26 / 11$ & 0 & 2 & 0 & 1 & 0 & 0 & 24 & 0 & 0 & 0 & 0 & 1 & 0 & 5 & 0 & 0 & 0 & 0 & 33 \\
\hline $3 / 12$ & 0 & 2 & 0 & 0 & 0 & 0 & 15 & 0 & 0 & 0 & 0 & 2 & 0 & 2 & 0 & 0 & 0 & 0 & 21 \\
\hline $10 / 12$ & 0 & 1 & 0 & 0 & 0 & 0 & 11 & 0 & 0 & 0 & 0 & 0 & 0 & 2 & 0 & 0 & 0 & 0 & 14 \\
\hline $17 / 12$ & 0 & 1 & 0 & 0 & 0 & 0 & 3 & 0 & 0 & 0 & 0 & 2 & 0 & 0 & 0 & 0 & 0 & 0 & 6 \\
\hline $24 / 12$ & 0 & 0 & 0 & 1 & 0 & 0 & 3 & 0 & 0 & 0 & 0 & 0 & 0 & 1 & 0 & 0 & 0 & 0 & 5 \\
\hline $31 / 12$ & 0 & 0 & 0 & 0 & 0 & 0 & 0 & 0 & 0 & 0 & 0 & 0 & 0 & 0 & 0 & 0 & 0 & 0 & 0 \\
\hline $7 / 1$ & 0 & 0 & 0 & 0 & 0 & 0 & 0 & 0 & 0 & 0 & 0 & 0 & 0 & 0 & 0 & 0 & 0 & 0 & 0 \\
\hline $14 / 1$ & 0 & 0 & 0 & 0 & 0 & 0 & 0 & 0 & 0 & 0 & 0 & 2 & 0 & 9 & 0 & 0 & 0 & 0 & 11 \\
\hline $21 / 1$ & 0 & 0 & 0 & 0 & 0 & 0 & 1 & 0 & 0 & 0 & 0 & 2 & 0 & 6 & 0 & 0 & 0 & 0 & 9 \\
\hline $28 / 1$ & 0 & 0 & 0 & 0 & 0 & 0 & 0 & 0 & 0 & 0 & 0 & 2 & 0 & 0 & 0 & 0 & 0 & 0 & 2 \\
\hline $4 / 2$ & 0 & 0 & 1 & 0 & 0 & 0 & 0 & 0 & 0 & 0 & 0 & 1 & 0 & 0 & 0 & 0 & 0 & 0 & 2 \\
\hline $11 / 2$ & 0 & 0 & 1 & 0 & 0 & 0 & 0 & 0 & 0 & 1 & 0 & 28 & 0 & 3 & 0 & 0 & 0 & 0 & 33 \\
\hline $18 / 2$ & 0 & 0 & 0 & 0 & 0 & 0 & 2 & 0 & 0 & 0 & 0 & 0 & 0 & 3 & 0 & 0 & 0 & 0 & 5 \\
\hline $25 / 2$ & 0 & 0 & 0 & 0 & 0 & 0 & 2 & 0 & 0 & 0 & 0 & 3 & 0 & 0 & 0 & 0 & 0 & 0 & 5 \\
\hline $4 / 3$ & 0 & 0 & 1 & 0 & 0 & 0 & 2 & 0 & 0 & 0 & 0 & 3 & 0 & 2 & 0 & 0 & 0 & 0 & 8 \\
\hline
\end{tabular}


$\begin{array}{llllllllllllllllllll}11 / 3 & 0 & 1 & 0 & 0 & 0 & 0 & 2 & 0 & 0 & 0 & 0 & 2 & 0 & 6 & 0 & 0 & 0 & 0 & 11\end{array}$

$\begin{array}{llllllllllllllllllll}18 / 3 & 0 & 0 & 0 & 0 & 0 & 0 & 6 & 0 & 0 & 0 & 0 & 3 & 0 & 2 & 0 & 0 & 0 & 0 & 11\end{array}$

$\begin{array}{llllllllllllllllllll}25 / 3 & 0 & 0 & 0 & 0 & 0 & 0 & 0 & 0 & 0 & 0 & 0 & 2 & 1 & 0 & 0 & 0 & 0 & 0 & 3\end{array}$

$\begin{array}{llllllllllllllllllll}1 / 4 & 0 & 0 & 0 & 0 & 0 & 0 & 0 & 0 & 0 & 0 & 0 & 0 & 0 & 1 & 0 & 0 & 0 & 0 & 1\end{array}$

$\begin{array}{llllllllllllllllllll}8 / 4 & 0 & 0 & 1 & 0 & 0 & 0 & 0 & 0 & 0 & 0 & 0 & 3 & 0 & 0 & 0 & 0 & 0 & 0 & 4\end{array}$

$\begin{array}{llllllllllllllllllll}15 / 4 & 1 & 0 & 0 & 0 & 0 & 0 & 4 & 0 & 0 & 0 & 0 & 5 & 0 & 7 & 0 & 0 & 0 & 0 & 17\end{array}$

$\begin{array}{llllllllllllllllllll}22 / 4 & 0 & 0 & 0 & 0 & 0 & 0 & 0 & 0 & 0 & 0 & 0 & 0 & 1 & 7 & 0 & 0 & 0 & 0 & 8\end{array}$

$\begin{array}{llllllllllllllllllll}29 / 4 & 0 & 0 & 1 & 0 & 0 & 0 & 0 & 0 & 0 & 0 & 0 & 0 & 0 & 8 & 0 & 0 & 0 & 0 & 9\end{array}$

$\begin{array}{llllllllllllllllllll}6 / 5 & 0 & 0 & 0 & 0 & 0 & 0 & 1 & 0 & 0 & 0 & 0 & 0 & 0 & 6 & 0 & 0 & 0 & 0 & 7\end{array}$

$\begin{array}{llllllllllllllllllll}13 / 5 & 0 & 0 & 0 & 0 & 0 & 0 & 1 & 0 & 0 & 0 & 0 & 0 & 0 & 1 & 0 & 0 & 0 & 0 & 2\end{array}$

$\begin{array}{llllllllllllllllllll}20 / 5 & 0 & 0 & 0 & 0 & 0 & 0 & 1 & 0 & 0 & 0 & 0 & 0 & 0 & 1 & 0 & 0 & 0 & 0 & 2\end{array}$

$\begin{array}{llllllllllllllllllll}27 / 5 & 0 & 0 & 0 & 0 & 0 & 0 & 1 & 0 & 0 & 0 & 0 & 0 & 1 & 1 & 0 & 0 & 0 & 0 & 3\end{array}$

$\begin{array}{llllllllllllllllllll}3 / 6 & 0 & 0 & 0 & 0 & 0 & 0 & 0 & 0 & 0 & 0 & 0 & 0 & 0 & 2 & 0 & 0 & 0 & 0 & 2\end{array}$

$\begin{array}{llllllllllllllllllll}10 / 6 & 0 & 0 & 0 & 0 & 0 & 0 & 1 & 0 & 0 & 0 & 0 & 0 & 0 & 0 & 0 & 0 & 0 & 0 & 1\end{array}$

$\begin{array}{llllllllllllllllllll}17 / 6 & 0 & 0 & 0 & 0 & 0 & 0 & 0 & 0 & 0 & 0 & 0 & 0 & 0 & 2 & 0 & 0 & 0 & 0 & 2\end{array}$

\begin{tabular}{cccccccccccccccccccc}
$24 / 6$ & 0 & 0 & 0 & 0 & 0 & 0 & 0 & 0 & 0 & 0 & 0 & 0 & 0 & 2 & 0 & 0 & 0 & 0 & 2 \\
\hline Total & $\mathbf{2}$ & $\mathbf{3 0}$ & $\mathbf{1 5}$ & $\mathbf{5}$ & $\mathbf{0}$ & $\mathbf{1}$ & $\mathbf{6 9 1}$ & $\mathbf{0}$ & $\mathbf{0}$ & $\mathbf{6}$ & $\mathbf{4}$ & $\mathbf{8 1}$ & $\mathbf{8}$ & $\mathbf{1 9 8}$ & $\mathbf{0}$ & $\mathbf{0}$ & $\mathbf{0}$ & $\mathbf{0}$ & $\mathbf{1 0 4 1}$ \\
\hline
\end{tabular} 